Dinamika Kesehatan Jurnal Kebidanan dan Keperawatan Vol 10 No. 1 Juli 2019 ( ISSN: 2086-3454 EISSN: 2549-4058) url: http://ojs.dinamikakesehatan.unism.ac.id DOI : https://doi.org/10.33859/dksm.v10i1

Hubungan Sikap Dan Kemampuan Ibu Nifas Tentang Cara Memandikan Bayi Di Wilayah Kerja Puskesmas S.Parman Banjarmasin

\title{
Hubungan Sikap Dan Kemampuan Ibu Nifas Tentang Cara Memandikan Bayi Di Wilayah Kerja Puskesmas S.Parman Banjarmasin
}

Sarkiah1 Fadhiyah Noor Anisa1 Rizqy Amelia1

Universitas Sari Mulia Banjarmasin

E-mail: fadhilsarkiah@gmail.com

DOI: https://doi.org/10.33859/dksm.v10i1.412

\begin{abstract}
Abstrak
Latar Belakang: Sekarang ini masih cukup tinggi angka kematian bayi salah satu penyebabnya adalah hipotermi. Salah satu penyebab hipotermi adalah ketidakpahaman dan ketidakmampuan ibu tentang cara memandikan bayinya dengan benar oleh karena itu bisa terjadi permasalah terhadap bayinya.

Tujuan: Mengetahui hubungan sikap dan kemampuan ibu nifas tentang cara memandikan bayi di wilayah kerja Puskesmas S.Parman Banjarmasin.

Metode: Penelitian menggunakan metode survei analitik dengan rancangan cross-sectional. Populasi ibu nifas di wilayah kerja Puskesmas S.Parman Banjarmasin berjumlah 199 orang. Sampel sebanyak 45 responden dengan teknik pengambilan Acidental sampling. Data dianalisis menggunakan uji chi square dengan tingkat kepercayaan $95 \%$.

Hasil: Responden di Puskesmas S.Parman Banjarmasin memiliki sikap positif yaitu 25 responden $(55,6 \%)$, dan memandikan bayi dengan cara yang tidak baik yaitu 24 responden $(53,3 \%)$. Hasil analisis menunjukkan ada hubungan antara sikap ibu $(p$-value $=0,021)$ dan kemampuan ibu nifas $(p$ value $=0,0001$ ) tentang cara memandikan bayi.
\end{abstract}

Simpulan: Ada hubungan sikap dan kemampuan ibu nifas tentang cara memandikan bayi di Wilayah Kerja Puskesmas S.Parman Banjarmasin.

Kata Kunci: Cara memandikan bayi, sikap, kemampuan, nifas. 


\begin{abstract}
ABSTRAK
Background: Now there is still a high rate of infant mortality, one of the causes is hypothermia. It is the lack of understanding and the inability of the mother to do baby-bathing properly her baby.

Purpose: Knowing the correlation between attitudes and postpartum mothers' abilities of about how to do baby-bathing in the working area of Puskesmas S.Parman Banjarmasin.

Method: The study used an analytical survey method with a cross-sectional design. The population was 199 people. The sample of 45 respondents with Accidental sampling technique. Data were analyzed using the chi-square test with a confidence level of $95 \%$.

Result: The respondents whose positive attitudes were 25 people $(55.6 \%)$, and did well baby-bathing were 24 people (53.3\%). The results of the analysis showed that there was a correlation between maternal attitudes $(\mathrm{p}$-value $=0.021)$ and the ability of postpartum mothers $(\mathrm{p}$-value $=0.0001)$ on how to bathe the baby.

Conclusion: There is a correlation between attitudes and postpartum mothers abilities on how to do baby-bathing in the working area of Puskesmas S.Parman Banjarmasin.
\end{abstract}

Keyword: How to do baby-bating, Attitude, ability, Postpartum.

\section{Pendahuluan}

\section{World Health Organization (WHO)}

pada tahun 2016 menjabarkan bahwa di dunia setiap tahunnya ada empat juta bayi meninggal pada periode neonatal (WHO, 2016). Adapun di Indonesia sekitar seperempat hingga separuh kematian bayi berumur kurang dari satu tahun terjadi dalam minggu pertama.

Setiap tahun sekitar 19 bayi per 1.000 kelahiran meninggal dalam rentang waktu 0 28 hari pasca kelahiran (Kemenkes RI, 2017).

\section{Bayi baru lahir belum mampu}

mengatur suhu tubuhnya secara langsung saat lahir dan dapat dengan cepat kedinginan, jika kehilangan panas tidak segera dicegah, bayi yang mengalami kehilangan panas kemudian terjadi hipotermi serta berisiko jatuh sakit dan meninggal (Hidayah, 2015). Berdasarkan data sekunder di wilayah kerja Puskesmas Terminal Kota Banjarmasin, terdapat 6 orang bayi baru lahir mengalami hipotermi (Puskesmas Terminal, 2017). Faktor untuk mencegah terjadinya hipotermi pada bayi baru 
Dinamika Kesehatan Jurnal Kebidanan dan Keperawatan Vol 10 No. 1 Juli 2019 ( ISSN: 2086-3454 EISSN: 2549-4058)

url: http://ojs.dinamikakesehatan.unism.ac.id DOI : https://doi.org/10.33859/dksm.v10i1

Hubungan Sikap Dan Kemampuan Ibu Nifas Tentang Cara Memandikan Bayi Di Wilayah Kerja

Puskesmas S.Parman Banjarmasin

lahir yaitu dengan memandikan bayi dengan

benar (Puspita, 2016).

Memandikan bayi adalah suatu cara membersihkan tubuh bayi dengan air dengan cara menyiram dan merendam diri dalam air berdasarkan urut-urutan yang sesuai (Zakiyyah, dkk. 2017). Memandikan bayi bagi ibu merupakan pekerjaan yang berat dan membingungkan karena kondisi tali pusat yang masih basah selain itu ibu juga takut akan terjadi infeksi karena kondisi tali pusat yang masih basah. Jika mereka mengetahui pedoman memandikan bayi karena sebelumnya sudah pernah memiliki anak maka hal itu bukanlah pekerjaan yang berat. Namun, tidak sedikit dari mereka yang tidak tahu bagaimana cara memandikan bayi (Hidayah, 2015).

Dampak memandikan bayi dengan cara yang tidak tepat dapat mengakibatkan kondisi yang buruk seperti celaka (jatuh dan tenggelam), air masuk ke dalam telinga atau hidung dan dapat menyebabkan bayi mengalami cold stress yang selanjutnya dapat menyebabkan hipotermia (Puspita, 2016).
Faktor-faktor yang berhubungan dengan cara ibu memandikan bayi adalah pengetahuan dan sikap (Notoatmodjo, 2012). Sikap berhubungan dengan cara ibu memandikan bayi. Sikap merupakan faktor yang ada pada setiap individu yang mendorong atau menimbulkan perilaku tertentu. Menurut Notoatmodjo (2012), Sikap itu selalu berhubungan dengan objek sikap yaitu terdapat hubungan yang positif dan negatif antara individu dengan objek tertentu sehingga hal ini akan menimbulkan sikap tertentu pula dari individu yang menjadi objek sikap. Adanya sikap yang negatif (tidak mendukung) dikarenakan ibu merasa takut anaknya akan merasa sakit, takut terjatuh atau anaknya cedera juga mengakibatkan ibu tidak mau memandikan bayinya.

Hasil penelitian yang dilakukan oleh Nidya (2012) tentang sikap Ibu tentang cara memandikan bayi di Puskesmas Tanjung Rema mendapatkan hasil bahwa dari 89 ibu, sebanyak 51 orang (57\%) bersikap negatif (Nidya, 2012). Selain itu, penelitian oleh Hidayah (2015) di Puskesmas Sungai Lulut 
Dinamika Kesehatan Jurnal Kebidanan dan Keperawatan Vol 10 No. 1 Juli 2019 ( ISSN: 2086-3454 EISSN: 2549-4058)

url: http://ojs.dinamikakesehatan.unism.ac.id DOI : https://doi.org/10.33859/dksm.v10i1

Hubungan Sikap Dan Kemampuan Ibu Nifas Tentang Cara Memandikan Bayi Di Wilayah Kerja

Puskesmas S.Parman Banjarmasin

Banjarmasin diketahui bahwa sikap ibu terkait

cara memandikan bayi dari 63 orang responden yang memiliki sikap negatif sebanyak 37 orang (59\%) (Hidayah, dkk. 2015).

Menurut data dari Dinas Kesehatan Kota Banjarmasin di wilayah kerja Puskesmas S.Parman memiliki cakupan ibu nifas yang mendapatkan pelayanan oleh tenaga kesehatan yang cukup banyak. Data dari bulan JanuariJuni 2018 diketahui jumlah ibu nifas sebanyak 199 orang. Dari jumlah ibu nifas tersebut diambil 10 responden untuk dijadikan sampel studi pendahuluan. Berdasarkan hasil studi pendahuluan, diketahui dari 10 ibu nifas didapatkan hasil 3 orang (30\%) ibu nifas dapat memandikan bayinya dengan baik. Ibu nifas yang dapat memandikan bayinya dengan baik dapat diketahui ketika ibu bias menyebutkan melalui tahapan-tahapan dalam memandikan bayi dengan cara yang benar. Sedangkan ibu nifas lainnya yaitu 7 orang (70\%) tidak dapat menyebutkan tahapan-tahapan cara memandikan bayi dengan benar. Hal ini disebabkan karena 7 orang $(70 \%)$ ibu nifas tersebut tidak memiliki kemampuan yang baik tentang cara memandikan bayinya. Selain itu, adanya sikap ibu nifas yang takut untuk memandikan bayinya, membuat 7 orang $(70 \%)$ ibu nifas tersebut merasa ragu-ragu dalam mempraktekkan bagaimana cara memandikan bayi serta biasanya dalam memandikan bayi ibu nifas biasanya juga dibantu oleh tenaga kesehatan atau kelaurga yang sudah bias memandikan bayi.

Berdasarkan data tersebut, peneliti tertarik untuk melakukan penelitian tentang hubungan sikap dan kemampuan ibu nifas tentang cara memandikan bayi di wilayah kerja Puskesmas S.Parman Banjarmasin.

\section{Tujuan}

Dari hasil penelitian ini peneliti ingin meningkatkan keterampilan ibu nifas tentang cara memandikan bayinya sehingga bisa menghindari permasalahan pada bayi seperti hipotermi.

\section{Bahan dan Metode}

Metode yang digunakan dalam hal ini adalah survei analitik yaitu mengidentifikasi hubungan sikap dan kemampuan ibu nifas 
Dinamika Kesehatan Jurnal Kebidanan dan Keperawatan Vol 10 No. 1 Juli 2019 ( ISSN: 2086-3454 EISSN: 2549-4058)

url: http://ojs.dinamikakesehatan.unism.ac.id DOI : https://doi.org/10.33859/dksm.v10i1

Hubungan Sikap Dan Kemampuan Ibu Nifas Tentang Cara Memandikan Bayi Di Wilayah Kerja

Puskesmas S.Parman Banjarmasin

tentang cara memandikan bayi dengan

pendekatan cross sectional. Pendekatan cross

sectional disebut juga penelitian transversal

sebab variabel bebas (faktor resiko) dan

variabel tergantung (efek) diobservasi hanya

sekali pada saat yang sama (Notoatmodjo,

2010).

Populasi penelitian ini adalah ibu nifas

yang ada di wilayah kerja Puskesmas

\begin{tabular}{cccccc}
\hline Kisi-Kisi & No & \multicolumn{4}{c}{ Pernyataan Sikap Ibu } \\
\cline { 2 - 6 } & & SS & S & TS & STS \\
\hline Waktu & 1 & $14(31,1 \%)$ & $6(13,3 \%)$ & $16(35,6 \%)$ & $9(20,0 \%)$ \\
\cline { 2 - 6 } Memandikan & 2 & $10(22,2 \%)$ & $26(57,8 \%)$ & $1(2,2 \%)$ & $8(17,8 \%)$ \\
\cline { 2 - 6 } & 3 & $6(13,3 \%)$ & $14(31,1 \%)$ & $14(31,1 \%)$ & $11(24,4 \%)$ \\
\cline { 2 - 6 } & 5 & $20(44,4 \%)$ & $0(0,0 \%)$ & $0(0,0 \%)$ & $25(55,6 \%)$ \\
\cline { 2 - 6 } & 6 & $7(15,6 \%)$ & $18(40,0 \%)$ & $10(22,2 \%)$ & $10(22,2 \%)$ \\
\cline { 2 - 6 } & 7 & $20(44,4 \%)$ & $0(0,0 \%)$ & $22(48,9 \%)$ & $3(6,7 \%)$ \\
\hline Persiapan & 13 & $8(17,8 \%)$ & $18(40,0 \%)$ & $13(28,9 \%)$ & $6(13,3 \%)$ \\
\cline { 2 - 6 } Memandikan & 15 & $11(24,4 \%)$ & $22(48,9 \%)$ & $10(22,2 \%)$ & $2(4,4 \%)$ \\
\hline Prosedur & 8 & $20(44,4 \%)$ & $42(93,3 \%)$ & $0(0,0 \%)$ & $0(0,0 \%)$ \\
Memandikan & 9 & $9(20,0 \%)$ & $18(40,0 \%)$ & $24(53,3 \%)$ & $0(0,0 \%)$ \\
\cline { 2 - 6 } & 10 & $20(44,4 \%)$ & $0(0,0 \%)$ & $0(0,0 \%)$ & $25(55,6 \%)$ \\
\hline Tujuan & 14 & $16(35,6 \%)$ & $4(8,9 \%)$ & $9(20,0 \%)$ & $16(35,6 \%)$ \\
\hline Memandikan & 11 & $0(0,0 \%)$ & $45(100 \%)$ & $0(0,0 \%)$ & $0(0,0 \%)$ \\
\hline S.Parm & 12 & $16(35,6 \%)$ & $4(8,9 \%)$ & $2(4,4 \%)$ & $23(51,1 \%)$ \\
\hline
\end{tabular}

S.Parman Banjarmasin dengan jumlah 199

orang ibu. Adapun sampel yang digunakan

pada penelitian ini sebanyak minimal 45

orang. Pengambilan sampel pada penelitian

ini di lakukan dengan teknik Acidental sampling.

\section{Hasil}

Hasil penelitian ini akan disajikan dengan menggunakan tabel distribusi untuk mengidentifikasi karakteristik responden.

Tabel 1 Distribusi karakteristik responden penelitian di Wilayah Kerja Puskesmas S.Parman

\begin{tabular}{lccc}
\hline Karakteristik & Kategori & Frekuensi & Persentase \\
\hline Umur & $20-30$ tahun & 40 & $88,89 \%$ \\
\cline { 2 - 4 } & $31-35$ tahun & 5 & $11,11 \%$ \\
\hline Jumlah Anak & 1 anak & 19 & $42,2 \%$ \\
\cline { 2 - 4 } & 2 anak & 22 & $48,9 \%$ \\
\cline { 2 - 4 } & 3 anak & 4 & $8,9 \%$ \\
\hline Pendidikan & SD/Sederajat & 4 & $8,9 \%$ \\
\cline { 2 - 4 } Terakhir Ibu & SMP/Sederajat & 8 & $17,8 \%$ \\
\cline { 2 - 4 } & SMA/Sederajat & 24 & $53,3 \%$ \\
\cline { 2 - 4 } & $\begin{array}{c}\text { Perguruan } \\
\text { Tinggi }\end{array}$ & 9 & $20,0 \%$ \\
\hline
\end{tabular}

Dari tabel di atas menunjukan bahwa

karakteristik responden yang menjadi sampel

penelitian paling banyak dari kelompok umur

20 - 30 tahun $(88,89 \%)$, memiliki jumlah anak

2 orang (48,9\%), dan memiliki latar belakang

pendidikan terakhir SMA/Sederajat $(53,3 \%)$.

Tabel 2 Distribusi Frekuensi Jawaban Kuesioner Sikap dalam Memandikan Bayi di Wilayah Kerja Puskesmas S.Parmanl Banjarmasin

Berdasarkan hasil jawaban kuesioner sikap tentang memandikan bayi, paling banyak responden menjawab setuju terhadap pernyataan positif tentang tujuan memandikan bayi yaitu memandikan bayi untuk mengurangi resiko terjadinya infeksi sebanyak 45 responden (100\%) dan sebelum memandikan bayi ibu menyiapkan semua perlengkapan mandi sebanyak 42 responden $(93,3 \%)$ 
Dinamika Kesehatan Jurnal Kebidanan dan Keperawatan Vol 10 No. 1 Juli 2019 ( ISSN: 2086-3454 EISSN: 2549-4058)

url: http://ojs.dinamikakesehatan.unism.ac.id DOI : https://doi.org/10.33859/dksm.v10i1

Hubungan Sikap Dan Kemampuan Ibu Nifas Tentang Cara Memandikan Bayi Di Wilayah Kerja

Puskesmas S.Parman Banjarmasin

Tabel 3 Distribusi Frekuensi Sikap Ibu di Wilayah Kerja Puskesmas S.Parman Banjarmasin

\begin{tabular}{ccc}
\hline Sikap & Frekuensi & Persentase (\%) \\
\hline Negatif & 20 & 44,4 \\
\hline Positif & 25 & 55,6 \\
\hline Jumlah & 45 & 100 \\
\hline
\end{tabular}

Berdasarkan hasil perhitungan skor sikap masing-masing responden dari hasil jawaban kuesioner, maka dikategorikan sikap responden dalam memandikan bayi yaitu paling banyak ibu dengan sikap positif yaitu sebanyak 25 responden $(55,6 \%)$.

Tabel 4 Distribusi Frekuensi Kemampuan ibu nifas tentang cara memandikan Bayi di Wilayah Kerja Puskesmas S.Parman Banjarmasin

\begin{tabular}{ccc}
\hline $\begin{array}{c}\text { Kemampuan Ibu } \\
\text { Memandikan Bayi }\end{array}$ & Frekuensi & Persentase (\%) \\
\hline Tidak Baik & 24 & 53,3 \\
\hline Baik & 21 & 46,7 \\
\hline Jumlah & 45 & 100 \\
\hline
\end{tabular}

Berdasarkan hasil penelitian di wilayah

kerja Puskesmas S.Parman Banjarmasin, diketahui bahwa ibu cenderung melakukan cara memandikan bayi yang tidak baik yaitu sebanyak 24 responden $(53,3 \%)$.

\section{Sikap Ibu}

Berdasarkan hasil jawaban kuesioner sikap tentang memandikan bayi, paling banyak responden menjawab setuju terhadap pernyataan positif tentang tujuan memandikan bayi yaitu memandikan bayi untuk mengurangi resiko terjadinya infeksi sebanyak 45 responden (100\%) dan sebelum memandikan bayi ibu menyiapkan semua perlengkapan mandi sebanyak 42 responden $(93,3 \%)$

Fakta lapangan menunjukkan ibu cenderung lebih banyak memiliki sikap positif dalam memandikan bayi dikarenakan faktor pengalaman yang pernah dilakukan ibu pada anak sebelumnya. Rata-rata ibu yang memiliki sikap positif terdapat pada ibu yang saat ini sudah memiliki anak kedua dan ketiga. Hal ini sesuai dengan teori dalam buku Notoatmodjo (2012) bahwa beberapa ciri-ciri sikap yang membedakan sikap antara seseorang dengan orang lain, yaitu sikap itu tidak dibawa sejak lahir, sikap itu terbentuk atau dibentuk, maka sikap itu dapat dipelajari karena itu sikap dapat berubah. Untuk pembentukan sikap diperlukan adanya faktor pengalaman dan sikap dalam manisfestasinya mengalami perubahanperubahan.

Sejalan dengan hasil penelitian Fondarizki (2015) bahwa sikap responden terhadap memandikan bayi paling banyak yang bersikap positif sebanyak 19 orang ibu nifas $(59,9 \%)$ dibandingkan yang bersikap 
Dinamika Kesehatan Jurnal Kebidanan dan Keperawatan Vol 10 No. 1 Juli 2019 ( ISSN: 2086-3454 EISSN: 2549-4058)

url: http://ojs.dinamikakesehatan.unism.ac.id DOI : https://doi.org/10.33859/dksm.v10i1

Hubungan Sikap Dan Kemampuan Ibu Nifas Tentang Cara Memandikan Bayi Di Wilayah Kerja

Puskesmas S.Parman Banjarmasin

negatif sebanyak 15 orang ibu nifas $(44,1 \%)$.

Responden yang memiliki sikap positif karena

adanya pengalaman pribadi. Pengalaman

pribadi tersebut meninggalkan kesan yang

kuat d dalam responden sehingga menjadi

sebuah pembelajaran untuk responden

tersebut.

\section{Cara Memandikan Bayi}

Kemampuan ibu merawat bayi seperti halnya dalam memandikan bayi bisa dipengaruhi oleh pengetahuan dan sikap. Sesuai dengan hasil penelitian yang didapat di Wilayah Kerja Puskesmas T Banjarmasin, dari 24 responden memiliki perilaku cara memandikan bayi yang tidak baik, paling banyak berasal dari responden yang memiliki pengetahuan rendah sebanyak 20 responden $(83,3 \%)$ dengan latar belakang pendidikan terakhir paling banyak masih rendah (SD dan SMP). Selain itu, dari 24 responden yang memiliki perilaku cara memandikan bayi tidak baik sebagian besar responden memiliki sikap yang negatif yaitu sebanyak 16 responden $(66,67 \%)$
Fakta lapangan yang menjelaskan kemampuan ibu cenderung lebih banyak masuk kategori tidak baik dilihat dari karakteristik dari 45 responden hanya ditemukan 9 responden $(20,0 \%)$ dengan latar belakang pendidikan di perguruan tinggi sedangkan sisanya dengan latar belakang pendidikan Sekolah Dasar (SD/Sederajat) sebanyak 4 responden $(8,9 \%)$, Sekolah Menengah Pertama (SMP/Sederajat) sebanyak 8 responden (17,8\%), dan Sekolah Menengah Atas (SMA/Sederajat) sebanyak 24 responden $(53,3 \%)$. Sedikitnya responden dengan tingkat pendidikan di perguruan tinggi tersebut menjadi salah satu alasan banyaknya responden yang memiliki tingkat pengetahuan tentang cara memandikan bayi yang masuk kategori pengetahuan tidak baik.

\section{Hubungan antara Sikap dengan kemampuan ibu memandikan Bayi}

Hasil penelitian menunjukkan bahwa ibu dengan sikap yang negatif cenderung melakukan cara memandikan bayi dengan tidak baik sebesar 15 responden $(75,0 \%)$ dibandingkan ibu yang memiliki sikap positif 
Dinamika Kesehatan Jurnal Kebidanan dan Keperawatan Vol 10 No. 1 Juli 2019 ( ISSN: 2086-3454 EISSN: 2549-4058) url: http://ojs.dinamikakesehatan.unism.ac.id DOI : https://doi.org/10.33859/dksm.v10i1

Hubungan Sikap Dan Kemampuan Ibu Nifas Tentang Cara Memandikan Bayi Di Wilayah Kerja Puskesmas S.Parman Banjarmasin

cenderung banyak yang melakukan cara memandikan bayi dengan baik yaitu sebesar 16 responden $(64,0 \%)$.

Sikap yang dimiliki ibu akan searah dengan perilaku yang di dilakukan ibu. Jika dalam diri ibu memiliki sikap negatif tentang cara memandikan bayi maka secara otomatis ibu akan melakukan cara memandikan bayinya tidak baik dan sebaliknya jika dalam diri ibu memiliki sikap positif tentang cara memandikan bayi maka ibu akan melakukan cara memandikan bayi dengan baik. Sikap yang ada pada ibu tersebut tentunya dibentuk atas dasar pengetahuan yang dimiliki ibu. Akan tetapi ada 5 orang ibu yang bersikap negatif, tapi mereka bersikap positif dalam memandikan bayi. Hal ini bisa disebabkan oleh sikap dan pengalaman ibu.

Berdasarkan hal tersebut, himbauan kepada bidan untuk memperhatikan kebutuhan informasi yang harus dimiliki ibu terutama ibu yang pertama kali melahirkan. Bidan harus memberikan pendidikan kesehatan kepada ibu untuk melakukan perawatan bayi baru lahir seperti memandikan bayi. Pendidikan kesehatan tersebut dapat dilakukan pada saat trimester III sampai saat ibu melahirkan.

Sesuai dengan teoiri Notoadmodjo (2002) bahwa sikap adalah keteraturan tertentu dalam hal perasaan, pemikiran, predisposisi tindakan seseorang terhadap suatu aspek dilingkungan sekitarnya. Notoatmodjo berpendapat bahwa sikap merupakan kesiapan atau kesediaan untuk bertindak dan bukan merupakan pelaksaan motif tertentu. Sikap belum merupakan suatu tindakan atau aktifitas, tetapi merupakan predisposisi tindakan suatu perilaku. Salah satu faktor yang memegang peranan penting dalam penentuan sikap adalah pengetahuan.

\section{Ucapan Terima Kasih}

Saya sangat berterima kasih Universitas Sari Mulia yang telah memberikan ijin kepada saya untuk bisa menjalankan tridharma Perguruan tinggi dan kepala Kepala Puskesmas S.Parman Banjarmasin yang telah memberikan izin dan tempat untuk melakukan penelitian serta kepada kelaurga dan orang tua. 


\section{Daftar Pustaka}

Andriani W. 2012. Gambaran Kemampuan Ibu Primipara dalam Memandikan Bayi di Kelurahan Polewali Kabupaten Polman. Skripsi. Makasar: Universitas Islam Negeri Alauddin [Internet]. Tersedia dalam: http://repositori.uinalauddin.ac.id/3191/1/WIWIK\%20AN DRIANI.pdf [Diakses 20 Mei 2018].

Fondarizki A. 2015. Gambaran Pengetahuan dan Sikap Ibu Nifas Tentang Cara Memandikan Bayi yang Baik dan Benar di BPS Sariwati Jl.Pekauman Banjarmasin Tahun 2015. Artikel Penelitian Bunga Kalimantan.

Hidayah N, Santoso BR, Melani. 2015. Gambaran Pengetahuan dan Sikap Ibu Nifas Primipara Tentang Memandikan Bayi Di Wilayah Kerja Puskesmas Sungai Lulut Banjarmasin. Jurnal Dinamika Kesehatan, 6 (2): 41-53 [Internet]. Tersedia dalam: http://ojs.dinamikakesehatan.stikessari mulia.ac.id/index.php/dksm/article/view 134/24 [Diakses 2 Februari 2018].

Kementerian Kesehatan RI. 2017. Kondisi Pencapaian Program Kesehatan Anak Indonesia. Jakarta: Infodatin Kemenkes RI [Internet]. Tersedia dalam: http://www.depkes.go.id/article/view/15 021800001/kondisi-pencapaian-

program-kesehatan-anak-indonesia.html [Diakses 3 Februari 2018].

Notoatmodjo, Soekidjo. 2007. Promosi Kesehatan dan Ilmu Perilaku. Jakarta: Rineka Cipta.

\section{Metodologi Penelitian}

Kesehatan. Jakarta: Rineka Cipta. 2010. Metodelogi Penelitian

Kesehatan. Jakarta : Rineka Cipta.
2012. Pendidikan Dan

Perilaku Kesehatan. Jakarta: Rineka Cipta.

Pramawati I. 2017. Faktor-Faktor yang Behubungan dengan Kejadian Hipotermi pada Neonatus di RSUD Dr. Moewardi. Surakarta: Artikel Ilmiah Stikes Kusuma Husada [Internet]. Tersedia dalam: http://www.repository.uinjkt.ac.id/dspa ce/bitstream/123456789/28070/1/MEG A\%20PERTIWI-FKIK.pdf [Diakses 2 Februari 2018].

Puspita IR. 2016. Insidens dan Faktor Risiko Hipotermia Akibat Memandikan Bayi Baru Lahir. Tesis. Universitas Indonesia [Internet]. Tersedia dalam: https://saripediatri.org/index.php/saripediatri/article/view/781 [Di akses 2 Februari 2018].

World Health Organization. 2016. World Health Statistik; Monitoring Health For The SDGs. USA: WHO States [Internet]. Tersedia dalam: http://www.who.int/gho/publications/w orld_health_statistics/2016/en/ [Diakses 5 Februari 2018].

Zakiyyah M. Ekasari T. Hanifah I. 2017. Pendidikan Kesehatan Dan Pelatihan Memandikan Bayi. Jurnal Pengabdian Kepada Masyarakat. 1 (1): 29-36 [Internet]. Tersedia dalam: http://ojshafshawaty.ac.id/index.php/jpe ngmas/article/view/6 [Diakses 5 April 2018].

Zuliayanti NI. 2013. Hubungan Penyuluhan Memandikan Bayi terhadap Cara Ibu Memandikan Bayinya di Puskesmas Banyuurip Kabupaten Purworejo. Artikel Penelitian Akbid Purworejo. [Internet]. Tersedia dalam: ejournal.akbid-

purworejo.ac.id/index.php/jkk10/article/ download/109/100 [Diakses 8 Agustus 2018]. 